\title{
Original
}

\section{Vocal nodules in a colombian teachers group with dysphonia}

\section{Prevalencia de nódulos vocales en un grupo de docentes con disfonía}

\author{
Andrés Felipe Alvarado Díaz ', Carlos Eduardo Pinzón ', José Rafael Tovar Cuevas ${ }^{2}$, Adriana Fajardo Hoyos ${ }^{1}$ \\ 1. Specialist in Occupational Health Universidad del Rosario. Colombia. \\ 2. Center for Research in Health Sciences, School of Medicine and Health Sciences, Universidad del Rosario. \\ Colombia.
}

Recibido: 19-09-13

Aceptado: 18-10-13

\section{Correspondencia}

José Rafael Tovar Cuevas

Centro de Investigaciones en Ciencias de la Salud (CICS)

Carrera 24 No 63 C69 Barrio Siete de Agosto

Santa Fe de Bogotá. Colombia.

57-1-3474570 ext 313

rtovar34@hotmail.com

Resumen

Introducción: Este estudio determina la prevalencia de nódulos Vocales asociados a disfonía en docentes con edades entre 35 y 65 años, considerando variables del individuo y ocupacionales.

Método: Estudio de corte descriptivo que incluyó la información contenida en 262 Historias Clínicas de docentes diagnosticados con disfonía en la consulta de medicina laboral en una IPS de la ciudad de Bogotá entre marzo de 2009 a marzo de 2012. La presencia de nódulos laríngeos se estableció a partir del hallazgo de nasofibrolaringoscopia.

Resultados: Se evidenció presencia de nódulos en 67 docentes que corresponde a una prevalencia del 25,5 \%, observándose mayores proporciones entre: mujeres, individuos con edades entre 45 y 54 años ( $\mathrm{p}=0.018)$, individuos con nivel de desempeño preescolar y docentes de educación física. En el grupo de docentes con nódulos, el 76,1\% tenían menos de cinco consultas médicas y el $75 \%$ tenía más de 90 días de incapacidad.

Conclusión: Un alto porcentaje de docentes con disfonía presentan nódulos vocales lo cual puede estar relacionado con diferentes variables como sexo, edad, tipo de nódulo, área y nivel de desempeño. La presencia de nódulos genera un alto número de incapacidades y un ausentismo laboral importante.

Med Segur Trab (Internet) 2013; 59 (233) 375-382

Palabras clave: Nódulos vocales, disfonía, docentes, incapacidad laboral.

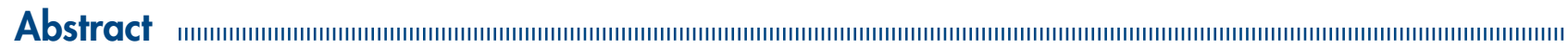

Objectives: This study determined the prevalence of vocal nodules associated with dysphonia in teachers aged from 35 to 65 years, taking into consideration both individual and occupational variables.

Methodology: Descriptive study that included the information contained in 262 medical records of teachers diagnosed with dysphonia in occupational health consultations at the institutions that provide health services in Bogotá, Colombia from March 2009 to March 2012. The presence of laryngeal nodules was based on the findings of a nasofibrolaryngoscopy procedure. 
Results: Nodules were found in 67 teachers, which corresponded to a rate of $25.5 \%$, being apparently (highest observed rates) associated primarily with the following variables: females, ages from 45 to 54 years, bilateral nodules, and teaching position (preschool and physical education). Of the teachers with nodules, $76.1 \%$ had fewer than five doctor's appointments, and $75 \%$ had more than 90 days of sick leave.

Conclusion: A high percentage of teachers have vocal nodules associated with dysphonia. This may be apparently related to different variables such as sex, type of nodule, area and teaching position. Was observed only a statistically significant association among presence of nodules and age $(\mathrm{p}=0.018)$. In addition this disorder generates a large number of incapacities and employee absenteeism.

Med Segur Trab (Internet) 2013; 59 (233) 375-382

Key words: Dysphonia, vocal nodules, basic school teachers. 


\section{INTRODUCTION}

Despite receiving support from technology and vocal education programs, the vocal disorders continue being present the teaching profession -either derived from vocal abuse or misuse- continue to occur, affecting teachers' performance. According to the literature reviewed ${ }^{1-13}$, from 11 to $64 \%$ of teachers have had symptoms of dysphonia at some point in their working life.

Vocal nodules, which are the most frequent benign lesions of the vocal cords, occur as a hypertrophy in the juncture of the anterior third and posterior two-thirds of the vocal folds, the site of greatest vibratory capacity ${ }^{14}$.

It was found that the presence of nodules results in teachers having to take periods of moderate-to-severe sick leave: 16.6 and 1.2\%, respectively. Some studies have found significant differences in vocal cord-related sick leave, depending on the diagnosis of vocal cord nodules, the prevalence of symptoms and the number of symptoms ${ }^{9}$. Therefore, it is important to determine the prevalence of vocal nodules in Colombian teachers who have dysphonia, given that there is no characterization applicable to this population. This could provide precise information about the prevalence of dysphonia associated with this pathology resulting from vocal abuse and/or misuse, which leads to the ineffective and inefficient functioning of the phonatory mechanism, resulting in an adverse impact on the professional performance of the teaching staff.

Characterization of this pathology will also provide a useful tool at the moment of establishing medical, rehabilitative and preventive interventions in this voice-intensive profession, making it possible to evaluate and create training programs that can enable them to continue improving the teachers' voices. Furthermore, this research supports the process of self-evaluation of preventive programs, enabling them to identify how effectively their actions have been oriented.

\section{SUBJECTS AND METHODS}

\section{Public-sector educators}

A descriptive cross-sectional study was done, using the information contained in 827 medical records of professional educators appointed to the Capital District. All the records corresponded to individuals who had been diagnosed with dysphonia, clinically assessed during an occupational health consultation in institutions that provided health services in Bogotá from March 2009 to March 2012. The total census of the teaching population with dysphonia during that period of time was also obtained. The target population was defined as all individuals aged from 35 to 65 years. The prevalence of laryngeal nodules was established on the basis of the findings of a nasofibrolaryngoscopy procedure.

Given that there was no information available on the prevalence of nodules in Colombian teachers, it was assumed to be $50 \%$, with a $10 \%$ margin of error for the breadth of the confidence interval and a $95 \%$ reliability of results. Based on those parameters, a sample size of 262 individuals was obtained, which included the maximum possible variability in the estimator of prevalence of nodules and the correction for the finite population. The following criteria were established for inclusion and exclusion of a subject:

- Criteria for inclusion:

- Be a professional educator appointed to the Capital District.

- Have gone to a doctor within the period from March 2009 to March 2012.

- Be from 35 to 65 years of age.

- Have gone to a doctor for dysphonia associated with work as a teacher.

- Have been diagnosed with a nasofibrolaryngoscopy performed by an otorhinolaryngologist during the period of time covered by the study. 
- Have a physical copy of the result of the nasofibrolaryngoscopy or a description of the same written by the Specialist who carried out the procedure.

- Criteria for exclusion:

- Teachers named in territorial entities other than the Capital District.

- Dysphonia with a diagnosis other than vocal nodules.

\section{Statistical analyses}

In the analyses of the data, percentages and confidence intervals (95\%) were calculated. Associations between variables were assessed by means of contingency tables and chi-squared tests. The information referring to the continuous variables was presented in the form of medians and ranges. The data were analyzed using SPSS version 20.

\section{RESULTS}

\section{Sociodemographic profile}

A total of 262 records were included (Table 1). There were 229 women (87.4\%): 86 of the individuals (32.8\%) were in Group 1 with ages under 40 or over 60 years; Group 2 had 69 patients (26.3\%) aged from 40-44 or 55-59 years; and Group 3 had the remaining 107 patients $(40.8 \%)$ with ages ranging from $45-54$ years.

Table 1. Distribution of individuals in the sample according to their sociodemographic characteristics

\begin{tabular}{|c|c|c|c|}
\hline & Variables & $\mathbf{n}$ & $\%$ \\
\hline \multirow[t]{2}{*}{ Gender } & Male & 33 & 13 \\
\hline & Female & 229 & 87 \\
\hline \multirow[t]{3}{*}{ Age } & $<40,>60$ years & 86 & 33 \\
\hline & $40-44$ and $55-59$ years & 69 & 26 \\
\hline & $45-54$ years & 107 & 41 \\
\hline \multirow{2}{*}{$\begin{array}{l}\text { Prevalence } \\
\text { of nodules }\end{array}$} & Yes & 67 & 26 \\
\hline & No & 195 & 74 \\
\hline \multirow{3}{*}{$\begin{array}{l}\text { Type of } \\
\text { nodules }\end{array}$} & Bilateral & 35 & 13 \\
\hline & Unilateral - left & 12 & 5 \\
\hline & Unilateral - right & 20 & 8 \\
\hline \multirow[t]{4}{*}{ Level } & Primary school & 102 & 39 \\
\hline & Secondary school & 137 & 52 \\
\hline & Preschool & 17 & 6 \\
\hline & Administration & 6 & 6 \\
\hline \multirow[t]{10}{*}{ Area } & Social sciences - philosophy & 27 & 10 \\
\hline & Humanities & 38 & 14.5 \\
\hline & Biology and chemistry & 24 & 9 \\
\hline & Physical education & 8 & 3 \\
\hline & Mathematics and physics & 17 & 7 \\
\hline & Computer science, technology and bookkeeping & 15 & 6 \\
\hline & Arts and music & 3 & 1 \\
\hline & Basic primary school (grades $1-5$ ) & 102 & 39 \\
\hline & Preschool & 17 & 7 \\
\hline & Administration & 11 & 4 \\
\hline \multirow[t]{6}{*}{ City zone } & Downtown & 15 & 6 \\
\hline & Chapinero & 6 & 2 \\
\hline & Northwest & 21 & 8 \\
\hline & North & 6 & 2 \\
\hline & West & 81 & 31 \\
\hline & South & 133 & 51 \\
\hline
\end{tabular}


Nodules were found in 67 patients (25.5\%), 35 of whom (52.2\%) had bilateral nodules according to the endoscopic diagnosis. As for gender, nodules were found in 59 women (25.76\%) and 8 men (24.24\%). All the men and $45.8 \%$ of the women had bilateral nodules (Table 2).

Based on age, the highest prevalence of nodules was observed among individuals in Group $3(34.6 \%, \mathrm{p}=0.018)$. Age groups 1 and 2 had a larger number of patients with bilateral rather than unilateral nodules (Table 2).

According to the level of education taught, the group of teachers with the highest prevalence of nodules was the preschool group (39\%) although statistically significant differences were not found in the prevalence of nodules among the groups of teachers at the different levels taught (Table 2). On the other hand, when taking into account the teaching position, the highest rate (50\%) was observed among the physical education teachers even when this result was not statistically significant (Table 2).

Table 2. Estimation of the rate of nodules according to characteristics of interest

\begin{tabular}{|c|c|c|c|c|c|}
\hline & Variables & $\begin{array}{l}\text { Rate of nodules } \\
\text { CI 95\% }\end{array}$ & Bilateral & Right & Left \\
\hline \multirow[t]{4}{*}{ Sex } & Masculine & 0,2424 & 8 & $0 \%$ & $0 \%$ \\
\hline & $\mathrm{n}=33$ & $(0.08-0.40)$ & $100 \%$ & & \\
\hline & Feminine & 0,2576 & 27 & 12. & 20 \\
\hline & $\mathrm{n}=229$ & $(0.20-0.32)$ & $46 \%$ & $20 \%$ & $34 \%$ \\
\hline \multirow[t]{6}{*}{ Aged } & $<40$ or $>60$ years & 0,1744 & 6 & 1 & 8 \\
\hline & $\mathrm{n}=86$ & $(0.09-0.26)$ & $40 \%$ & $7 \%$ & $53 \%$ \\
\hline & 40 to 44 and 55 to 59 & 0,2173 & 11 & 1 & 3 \\
\hline & $\begin{array}{l}\text { years } \\
\mathrm{n}=69\end{array}$ & $(0.11-0.32)$ & $73 \%$ & $7 \%$ & $20 \%$ \\
\hline & 45 to 54 years*** & 0,3457 & 18 & 10 & 9 \\
\hline & $\mathrm{n}=107$ & $(0.25-0.44)$ & $49 \%$ & $27 \%$ & $24 \%$ \\
\hline \multirow{6}{*}{$\begin{array}{l}\text { Academic } \\
\text { level }\end{array}$} & Basic school (grades & 0,2843 & 15 & 5 & 9 \\
\hline & $\begin{array}{l}1-5) \\
n=102\end{array}$ & $(0.20-0.38)$ & $52 \%$ & $17 \%$ & $31 \%$ \\
\hline & Secondary school & 0.228 & 16 & 8 & 7 \\
\hline & $\mathrm{n}=136$ & $(0.15-0.30)$ & $52 \%$ & $26 \%$ & $23 \%$ \\
\hline & Preschool* & 0.39 & 3 & 0 & 4 \\
\hline & $\mathrm{n}=18$ & $(17.3-64.3)$ & $75 \%$ & & $100 \%$ \\
\hline \multirow[t]{14}{*}{ Area } & Social sciences - & 0.4444 & 6 & 4 & 2 \\
\hline & $\begin{array}{l}\text { philosophy } \\
n=27\end{array}$ & $(0.24-0.65)$ & $50 \%$ & $33 \%$ & $17 \%$ \\
\hline & Humanities* & 0.1081 & 3 & 1 & 1 \\
\hline & $\mathrm{n}=37$ & $(0.03-0.25)$ & $75 \%$ & $25 \%$ & $25 \%$ \\
\hline & Biology and & 0.125 & 2 & 0 & 1 \\
\hline & $\begin{array}{l}\text { chemistry* } \\
\mathrm{n}=24\end{array}$ & $(0.03-0.32)$ & $66.66 \%$ & & $33.33 \%$ \\
\hline & Physical education* & 0.5 & 2 & 1 & 1 \\
\hline & $\mathrm{n}=8$ & $(0.16-0.84)$ & $50 \%$ & $25 \%$ & $25 \%$ \\
\hline & Mathematics and & 0,1764 & 2 & 1 & 0 \\
\hline & $\begin{array}{l}\text { physics* } \\
\mathrm{n}=17\end{array}$ & $(0.04-0.43)$ & $67 \%$ & $33 \%$ & \\
\hline & Computer science, & 0,2 & 1 & 1 & 1 \\
\hline & $\begin{array}{l}\text { technology and } \\
\text { bookkeeping* } \\
n=15\end{array}$ & $(0.04-0.48)$ & $33 \%$ & $33 \%$ & $33 \%$ \\
\hline & Arts and music* & 0.3333 & 1 & 0 & 0 \\
\hline & $\mathrm{n}=3$ & $(0.008-0.91)$ & $100 \%$ & & \\
\hline
\end{tabular}




\begin{tabular}{llrrrr}
\hline & Variables & $\begin{array}{c}\text { Rate of nodules } \\
\text { CI 95\% }\end{array}$ & Bilateral & Right & Left \\
\hline $\begin{array}{l}\text { Zone of } \\
\text { the city }\end{array}$ & Downtown & 0.2666 & 1 & 3 & 0 \\
& n=15 & $(0.18-0.55)$ & $25 \%$ & $75 \%$ & \\
& Chapinero & 0,5 & 1 & 0 & 2 \\
& n=6 & $(0.12-0.88)$ & $33 \%$ & & $67 \%$ \\
& Northwest & 0.3333 & 4 & 1 & 2 \\
n=21 & $(0.15-0.57)$ & $57 \%$ & $14 \%$ & $29 \%$ \\
North & 0.3333 & 2 & 0 & 0 \\
n=6 & $(0.04-0.78)$ & $100 \%$ & & \\
West & 0.3456 & 13 & 7 & 8 \\
& n=81 & $(0.24-0.46)$ & $46 \%$ & $25 \%$ & $29 \%$ \\
& South & 0.1729 & 14 & 2 & 7 \\
n=133 & $(0.11-0.24)$ & $61 \%$ & $9 \%$ & $30 \%$ \\
\hline
\end{tabular}

${ }^{*}$ The rates were calculated according to the number of individuals in each category. ${ }^{*} p=0.018$

\section{Work-related incapacities}

The results of the calculations that related the days of sick leave generated in the consultations according to the diagnosed pathology showed that illnesses other than vocal nodules generated fewer days of incapacity. Almost $63 \%$ of the individuals had fewer than 30 days of sick leave, and $81.3 \%$ had fewer than 5 consultations; whereas the majority of patients diagnosed with vocal nodules had the fewest consultations $(76.1 \%$ had fewer than five consultations, but the highest number of days of sick leave ( $75 \% \mathrm{had}$ more than 90 days of sick leave) (Table 3).

Table 3. Distribution of the individuals according to the diagnosis

\begin{tabular}{|c|c|c|c|c|c|c|}
\hline & & $\begin{array}{c}\text { Acute laryngitis } \\
\quad \mathbf{n}=\mathbf{2 7}\end{array}$ & $\begin{array}{c}\text { Gastroesophageal } \\
\text { reflux } \\
n=116\end{array}$ & $\begin{array}{c}\text { Acute } \\
\text { nasopharyngitis } \\
n=48\end{array}$ & $\begin{array}{c}\text { Phonasthenia } \\
\quad n=4\end{array}$ & $\begin{array}{c}\text { Vocal nodules } \\
\quad \mathbf{n}=\mathbf{6 7}\end{array}$ \\
\hline \multirow{4}{*}{$\begin{array}{l}\text { Days of sick } \\
\text { leave }\end{array}$} & & 24 & 113 & 1 & 0 & 9 \\
\hline & 31 to 60 & 1 & 1 & 8 & 0 & 5 \\
\hline & 61 to 90 & 0 & 0 & 1 & 0 & 3 \\
\hline & Over 90 & 2 & 2 & 38 & 4 & 50 \\
\hline \multirow{3}{*}{$\begin{array}{l}\text { Number } \\
\text { of medical } \\
\text { consultations }\end{array}$} & 1 to 5 & 27 & 116 & 36 & 2 & 51 \\
\hline & 6 to 10 & 0 & 0 & 12 & 2 & 12 \\
\hline & Over 11 & 0 & 0 & 0 & 0 & 4 \\
\hline
\end{tabular}

\section{DISCUSSION}

The data resulting from the relationship between dysphonia and teachers' age and sex were similar to those observed in some international studies ${ }^{15}$, where the female teachers (average age 43) in primary and secondary schools were the group of this voiceintensive profession in which dysphonia was commonest ${ }^{16}$ where the women teachers sought more medical assistance than the men; and at the time of the study, $38 \%$ of them had complaints related to the quality of their voices versus $13.2 \%$ for the men. In a random sample of teachers from the State of La Rioja, Spain ${ }^{11}, 63 \%$ of those who had voice-related disorders were women.

The primary laryngeal pathology associated with dysphonia in our country is vocal nodules, the prevalence of which is very high ${ }^{8}$. They also appear as the most frequent organic pathology (13.8\%) in studies of teachers with dysphonia in which the procedure of vídeolaryngostroboscopy was used ${ }^{11}$. 
The results for the prevalence of nodules by gender are in accordance with findings in other studies as that of Preciado et al. in which they found that organic lesions in the larynx of patients with dysphonia were more prevalent in women $(25.4 \%)$ than in men (9.5\%). With respect to the relationship between nodules and age group, the result was above the average age observed in other studies, where the mean age was 33 years.

As for the academic level, the findings in this study are similar to those of researchers who have observed teachers of primary school and of younger aged groups as having a greater risk of developing a voice disorder given that they have few opportunities to rest their voice during the workday ${ }^{10}$.

High rates of sick leave have been found in different Latin American countries, with the most frequent diagnosis of work-related consultations being voice disorders with the highest average of incapacities being for voice disorders in preschool teachers and administrative staff ${ }^{17}$. The average sick leave for teachers in other studies was 36.9 days, with dysphonia being the principal diagnosis ${ }^{18}$. A study of teachers in Venezuela had the highest rate of diagnoses for dysphonia (90.4\%) with a high number of work related incapacities ${ }^{19}$. Many studies concur that there is a high index of sick leave due to vocal disorders, a high percentage of which are associated with vocal nodules ${ }^{9,17}$. It is important to point out that, in this study we do not controlled other possible habits associated with the presence of nodules as use of tobacco/alcohol which can be considered a limitation of the study.

\section{REFERENCES}

1. Sapir S, Keidar A, Mathers-Schmidt B. Vocal attrition in teachers: survey findings. Eur J Disord Commun 1993; 28(2): 177-85.

2. Roy N, Merrill RM, Thibeault S, Gray SD, Smith EM. Prevalence of voice disorders in teachers and the general population. J Speech Lang Hear Res 2004; 47(2): 281-93.

3. Simberg S, Laine A, Sala E, Rönnemaa AM. Prevalence of voice disorders among future teachers. J Voice 2000; 14(2): 231-5.

4. Russell A, Oates J, Greenwood KM. Prevalence of voice problems in teachers. J Voice 1998; 12(4): $467-79$.

5. Urrutikoetxea A, Ispizua A, Matellanes F. [Vocal pathology in teachers: a videolaryngostroboscopic study in 1046 teachers]. Rev Laryngol Otol Rhinol 1995; 116(4): 255-62 (in French).

6. Da Costa V, Prada E, Roberts A, Cohen S. Voice disorders in primary school teachers and barriers to care. J Voice 2012; 26(1): 69-76.

7. Landazuri E. "Prevencion vocal", una responsabilidad fonoaudiológca en los profesionales de la voz; aportes de una investigación en locutores de Bogotá. UMBral 2008; 12: 33-51.

8. Tobar LN, Perez MC, Camacho J. Patología benigna de laringe en docentes y cantantes. Acta Otorrinolaringol CCC 2011; 39(1): 15-23.

9. Barbero-Díaz FJ, Ruiz-Frutos C, del Barrio Mendoza A, Bejarano Dominguez E, Alarcon Gey A. Incapacidad vocal en docentes en la provincia de Huelva. Med Segur Trab 2010; 56: 39-48.

10. Munier C, Kinsella R. The prevalence and impact of voice problems in primary school teachers. Occup Med 2008; 58(1): 74-6.

11. Preciado J, Perez C, Calzada M, Preciado P. Frequency and risk factors of voice disorders among teaching staff of La Rioja, Spain. Clinical study: questionnaire, function vocal examination, acoustic analysis and videolaryngostroboscopy. Acta Otorrinolaringol Esp. 2005; 56(4): 161-70.

12. Cantor Cutiva, LC. Analisis fono-ergonómico de la disfonia ocupacional en docentes: influencia del espacio físico en la presencia de la disfonia [MSc thesis]. Bogotá (Colombia): Univ. Nacional de Colombia; 2009.

13. Sliwinska-Kowalska M, Niebudek-Bogusz E, Fiszer M, Los-Spychalska T, Kotylo P, Sznurowska-Przygocka $\mathrm{B}$, Modrzewska M. The prevalence and risk factors for occupational voice disorders in teachers. Int $\mathrm{J}$ Phoniatrics, Speech Ther Commun Disord (Pathol) 2006; 58: 85-101.

14. Cervera FJ, Vega F, García-Tapia R. Lesiones benignas de las cuerdas vocales. In: García-Tapia R, Cobeta I, editors. Diagnóstico y tratamiento de los trastornos de la voz. Madrid (Spain): Garsi; 1996. p. 223-40. 
15. Kosztyla-Hojna B, Rogowski M, Rucza J, Pepinski W, Lobaczul S. An analysis of occupational dysphonia diagnosed in the north-east of Poland. Int J Occup Med Environ 2004; 17(2): 273-78.

16. Van Houtte E, Claeys S, Wuyts F, Van Lierde K. The impact of voice disorders among teachers: vocal complaints, treatment-seeking behavior, knowledge of vocal care, and voice-related absenteeism. J Voice 2010; 25(5): 570-5.

17. Barrreto-Munévar DP, Cháux-Ramos OM, Estrada-Rangel MA, Sánchez-Morales J, Moreno-Angarita M, Camargo-Mendoza J. Factores ambientales y hábitos vocales en docentes y funcionarios de pre-escolar con alteraciones de voz. Rev. Salud Pública 2011; 13(3): 410-20.

18. Pachón O, Peña M. Distribución de diagnósticos y su relación con los factores demográficos en docentes del magisterio [Thesis specialization]. Bogotá (Colombia): Univ. del Rosario; 2010. Available at http:// repository.urosario.edu.co/bitstream/10336/2838/1/33366653-2012.pdf.

19. Escalona E. Symptoms of voice disorders and prevalence of working conditions among primary school teachers. Aragua - Venezuela. Salud Trab 2006; 14(2): 31-54.

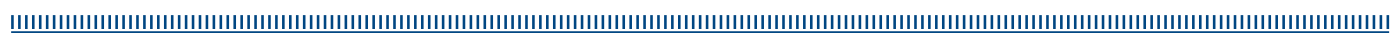

